\title{
GLOBAL OIL PRICES AND THE NIGERIAN LABOUR MARKET
}

\author{
DUMEBI, Ideh Anthony ${ }^{1}$ and OLUSANYA, Olasunmbo ${ }^{2}$ \\ Department of Employment Relations and Human Resource Management ${ }^{1,2}$ \\ Faculty of Management Sciences \\ University of Lagos \\ E-mails: ${ }^{1}$ dideh@unilag.edu.ng, ${ }^{2}$ sunmboolusanya@yahoo.com \\ DOI: 10.36108/ljerhrm/0202.02.0170
}

\begin{abstract}
Nigeria is both a major exporter of crude oil and major importer of refined petroleum products with high level of unemployment. Nigeria depends on oil for its revenue and as major input in most industrial sectors. This paper examined the opportunities created by the low global oil prices for improving the Nigerian labour market. The study adopted qualitative research approach. The key findings are that fall in oil price provides negative challenges for Nigerian labour market in the short-run but an opportunity for improved employment generation in the long-run. The study concludes that government should take advantage of the fall in oil price to develop other sectors of the Nigerian economy. The paper has contributed to knowledge by establishing among others, that low oil prices create opportunities for nations to improve the labour market conditions.
\end{abstract}

Keywords: Crude oil, economy, global, labour market, Nigeria

\section{Introduction}

Crude oil is an important source of revenue for many nations. It accounts for over 70 percent of Federal Government revenue in Nigeria (Baghebo\&Atima, 2013; Nlerum, 2010). The economy of Nigeria prior to the discovery of crude oil was largely agrarian and showed a lot of promise but began to shrink as a result of renewed dependence on oil revenue (Alley, Asekomeh, Mobolaji, Adeniran, 2014; Canagarajah\& Thomas, 2001). The discovery of crude oil in Nigeria has been traced to Oloibiri in the Niger Delta Region of Nigeria (Nwilo\&Badejo, 2012; Odularu, 2008). Nigeria is a major exporter of crude oil and at the same time, a major importer of refined petroleum products with high level of unemployment. Nigerian economy is heavily dependent on crude oil as it is a major input in all industrial sectors such as electricity generation, transportation, and manufacturing. Therefore, an increase in oil price increases input costs and hence increases in production cost and unemployment rate. At the same time, a decrease in the global oil price will affect the revenue accruable to Nigeria as it depends largely on oil for its revenue.

Conversely, the emergence and increased demand for 'Shale oil' has led to drastic reduction for crude oil from Sub-Saharan Africa. Although a little less than acceptable level of shale oil for economic exploitation has been discovered in the Benue Trough (Ekweozor\&Unomah, 1990), crude oil remains one of the most important energies used in the process of production in different industries and its price is determined in global arena and denominated in US dollar. Changes in the price of crude oil will in no small measure affect the economic activities of any nation and through many ways, as no independent economy is immuned from its effects (Bahadorkhah\&Aminifard, 2014; Senzangakhona\&Choga, 2015) 
Nigeria is not a stranger to oil price related crisis. The two previous episodes according to PWC (2015) resulted in a free falling Naira and slowing economic growth: for example, in 1986, the global oil glut that resulted from oversupply of oil built up in the 1980s, weak demand and development of new forms of energy led to global economic crisis. Average price of oil fell $48 \%$ between 1985 and 1986 and resulted in economic contraction over the next two years with Naira depreciating by over 70\%. Also, between 1997 and 1998, the oil price gradually declined in response to cooling demand as the financial crisis in Asia deepened. Although the Naira initially stood firm and the economy continued to grow, the deteriorating political situation led to a devaluation of Naira by $75 \%$ in 1999 (PWC, 2015).

There have been various studies (Bahadorkhah and Aminifard, 2014; Nwilo and Badejo, 2012; Odularu, 2008; Senzangakhona and Choga, 2015) in the areas of crude oil crisis and unemployment but a few of these works have looked at the implications of global oil crisis on Nigerian labour market. The purpose of this paper is therefore to examine the implications of decline in global oil prices in respect of opportunities presented to improve the Nigerian labour market. This paper is divided into 5 sections and commenced with the introduction, followed by review of related literature, then method and methodology. Section 4 was used for discussions while the paper draws conclusion and made recommendations in section 5 .

\section{Review of Related Literature}

Nigeria, which is the most populous country within the Organization of Petroleum Exporting Countries (OPEC) has a population of over 178.2 million people, and a total of 17.7 million people between ages 15 and 65 either unemployed or underemployed in the first quarter of 2015 (Omorogiuwa, 2014; OPEC, 2016). The labour market is the means by which participants earn income and improve their lot and that of their dependants(Ogwumike, Alaba, Alaba, Alayande, \&Okojie, 2006) thus, sustainable jobs for willing participants are desirable. Achieving full employment is an important macroeconomic and socio-political challenge that governments in both developed and developing nations encounter. Therefore, every government makes policies that focus on reduction of unemployment rate in its nation. Policy makers in different economies understand the fact that factors that affect unemployment differ from one nation to the other. With regards to the difference in the level of unemployment between developed and developing nations, Bahadorkhah and Aminifard (2014) argue that developing countries are known to have higher unemployment rates than developed countries. This is because while developed nations make policies to increase employment, higher products demand, and resources for production and higher per-capita income, developing economies have high unemployment rate because of lower demand for products, insufficient resources and lower per-capita income (Ahmad, 2013).

Unemployment phenomenon is largely caused by the imbalance in the labour market. It is in this regards that Bahadorkhah and Aminifard (2014) state that when considering unemployment from the supply framework, the level of employment in any society could depend on factors such as the productivity of labour, wages, price level and prices of other factors of production. While on the macroeconomic level, unemployment rate will follow such local factors as the state of the economy, business cycle, the level of technology, the demographic factors and other global factors such as price of energy. 
A major impact of oil price increases on economy of an oil exporting countries such as Nigeria is the Dutch Disease Syndrome. Dutch disease phenomenon is used to explain the channel through which revenue from crude oil can affect economic activities and unemployment. According to Bahadorkhah and Aminifard (2014)), Dutch disease phenomenon contributes to a situation in which the unexpected and sudden increase in crude oil price leads to the increase in the real rate of exchange and reduction in production and employment in other sectors. The effect of Dutch diseases in oil exporting countries such as Nigeria is the increase in national income from oil sector while production and growth of non-oil sectors of the economy decline and unemployment increases.

\section{Crude Oil and the Nigerian Economy}

In the Nigerian context, crude oil has boosted gross domestic product and foreign exchange reserves, as well as created employment opportunities in construction of roads and bridges, clearing of drilling sites, transportation of materials and equipment, and the building of staff housing and recreational facilities (Odularu, 2008). Thus, sale of crude oil has undoubtedly been beneficial to the Nigerian economy as the economy depends largely on the revenue from oil. High price of crude oil has made positive impacts on the Nigerian economy over the last decades. Among the areas that have benefited from increase in crude oil price include; increase in government revenue and creation of employment. Crude oil has contributed positively to the growth of Nigerian economy. For example, the greater percentage of the nation's revenue is dependent on income from crude oil. The revenue from crude oil has acted as a source of finance for government projects, meeting internal and external debt obligations and other commitments. More so, major industrial sector depend on crude oil products for their production activities.

Nevertheless, it has been observed that the oil boom of the 1970s led to the deterioration of financial discipline and accountability in Nigeria (Agbaeze, Udeh\&Onwuka,2015). Odularu (2008) observed that the impacts of oil exploration in the host communities have been adverse, particularly in terms of oil spills. Oil spillage has deprived local communities of their sources of livelihood, which are predominantly fishing, and farming. As a result, one might ask if this loss of livelihood has been adequately compensated through oil revenue. In this regard, Odularu (2008) noted that up to 80 percent of oil revenue in Nigeria benefits only about one per cent of the populace. This suggests that the system of wealth distribution is defective.

It has been argued that the discovery of crude oil in Nigeria, particularly in relation to exploration and production have resulted in negatives such as oil spillage, pollution, unemployment, poverty among others and is short of a blessing to the country (Baghebo\&Atima, 2013; Tamuno\& Felix, 2006). Baghebo and Atima (2013) contended that the problem with the Nigerian economy relates to the failure of successive governments to develop other sectors of the economy with oil revenue. Although, the exploration and sale of crude oil has provided some jobs in Nigeria, the contributions of the sector to employment generation, which is 1.3 percent of modern sector employment, has not been robust due to limited linkages with the rest of the Nigerian economy (Ibrahim, 2007; Odularu, 2007).

Oil has impacted negatively on the economy of Nigeria and the labour market. Nigerian economy is highly dependent on oil revenue but this has not been translated into wealth for sustainable development. The mono-product economy makes Nigerian economy vulnerable to 
external shocks and subjects it to development of different forms of limitations. Nigerian economy has depended on oil to the disadvantage of other sectors.

\section{Effects of Declining Oil Prices on the Labour Market}

It has been argued that when an economy overly depend on natural resources, it invariably leads to poor investment in human capital, unbalanced allocation of resources and instability (Agbaeze, Udeh, \&Onwuka,2015;Gylfason, 2001; Osigwe, 2015; Rosser, 2006). Thus, the dependence of the Nigerian economy on revenue from sale of crude oil has made the country most vulnerable to changes in the price of crude oil in the global market and unable to harness the full potential of other sectors of the economy. In addition, the volatility of exchange rates as a result of the fall in crude oil price in the international market puts pressure on household goods (Osigwe, 2015) thereby reducing the purchasing power of individuals at current income levels.

However, since the government in Nigeria is still the largest employer of labour, workers are at risk of being unemployed as a result of efforts to prioritise capital expenditure over recurrent expenditure. This may undermine efforts to create new jobs in the public sector because some studies have called for the reduction of government's recurrent expenditure to invest the savings in other sectors of the economy (Aigheyisi, 2013; Chude\&Chude, 2013; Oluwatobi\&Ogunrinola, 2011). Fall in oil price also has negative effect on growth and development in the economy because less revenue accruing to the government means reduced spending. Furthermore, since government is the single largest employer of labour in Nigeria, a fall in oil revenue will lead to tightening of the labour market as government will have less to spend and may put restriction on staff recruitment, training and development and other welfare packages for the workers.

Also, another negative implication of the fall in global oil price is the decline in revenue that accrues to the three tiers of government in Nigeria (Federal, State and local Government). There are therefore, clear challenges as a large number of State governments could not pay their workers' salaries and have to depend on the Federal government for bailout fund. For the local government, workers are being owed salaries for over 9 months. The obvious thing is that the proper execution of budget at the three tiers of government has been difficult.

\section{Methodology}

The research methodology adopted by this study fits into exploratory qualitative research method and the data were collected from secondary sources.Keshinro (2014) stated that the qualitative research method is used to seek and understand meanings, describe and understand experience, ideas, beliefs, and values. Secondary source of data unlike the primary source does not require access to respondents or subjects (Ember and Levinson, 1991) and are usually used to describe another researcher's report (Gravetter\&Forzano, 2009). Some of the disadvantages of secondary sources of data collection include; lack of control over the quality of data (Saunders, Thornhill and Lewis, 2009) and bias and inappropriate application of the data collected (Denscombe, 2010). This study however took adequate care in drawing conclusions from the data collected so as to minimise the disadvantages associated with secondary sources of data collection. The data for this study were gathered from official government documents; review of published journal articles, newspapers and magazines and from internet materials. 


\section{Discussions}

\section{Opportunities Available to Improve the Nigerian Labour Market}

It has been suggested that complete dependence on oil is not sustainable and that there is an urgent need to diversify the Nigerian economy (Agbaeze, Udeh\&Onwuka, 2015). Sanusi (2010) noted that a sustainable economy is that which promotes all-inclusive and non-inflationary growth. This would ensure that the economy performs at its full capacity, thereby exploring all potential income generation sectors of the economy. Nigeria as a developing nation with developing institutions and governance structure faces significant challenges in building a stable business environment as investors still find it difficult to do business in Nigeria judging from the 2014, World Bank Ease of doing Business Index that ranked Nigeria $170^{\text {th }}$ out of 189 nations (PWC, 2015). Although this position has improved, it is however not yet satisfactory for investors in Nigeria.

Umoru and Yaqub (2013) observed that the demand for labour has been poor and volatile in Nigeria and that this is a reflection of what drives the economy because it is the production and distribution activities in the goods and services sectors that are the major determinants of demand for labour. Therefore, following the fall in the price of crude oil and the clamour for diversification, efforts geared towards earning foreign exchange from multi-products should place emphasis on engaging excess supply in the Nigerian labour market to reduce rate of unemployment. This reinforces the suggestion that Nigeria should leverage on the sizeable population to promote inclusive growth (Sanusi, 2010).

Although administrative improvements in form of increased tax, reduction in spending among others may improve the revenue profile of the government in the short run, it is our belief that more ambitious programmes will be needed to put Nigeria off the track of dependence on oil as source of revenue at the long run. Nigerian economy can easily overcome any fall in oil price if the domestic growth fundamental are strong. Therefore, the current low oil prices will act as push factors that will enable Nigerian policy makers strengthen the domestic growth fundamentals to reduce Nigerian dependency on oil for its revenue. Unemployment in most cases is a function of the abandonment of government job creation schemes. Therefore, development of agriculture and other services discussed below will help to insulate the real economy from dwindling global oil prices and hence improve the employment rate in the country.

\section{Improving the labour market through revamping agricultural sector}

Omorogiuwa (2014) observed that 75 percent of Nigeria's land is suitable for agricultural purposes but that only 40 percent is currently in use for this purpose. Therefore, Nigeria is currently operating below capacity in terms of its potential for agricultural production. Therefore, huge investment in Agricultural schemes is proposed in the 'post sole dependence on crude oil Nigeria'. Agriculture was the dominant sector of the economy contributing about 70 per cent of the gross domestic product (GDP), employing about 75 per cent of the working population and accounting for about 90 per cent of foreign earning and government revenue (Oladipo \&Fabayo, 2012; Fajana, 2000). Agricultural sector will be a major strategy by government in their quest to re-build the economy. 
It is noted by Fajana (2000) that unemployed graduates will have more jobs if substantial investment is made in the agricultural sector. Revamping the agricultural sector will help in reducing unemployment, flourishing the production of raw materials and food as was the case before the oil boom of 1970 s and improve revenue generation which will return agriculture as the key revenue driver for the country. In analysing the benefits derivable from agricultural produce, Tiku and Bullem (2015) argued that Oil Palm is a versatile agricultural product, which has the potential to enhance Nigeria's economic development efforts. The food uses include: cooking, frying, baking, desserts, spreads and infant nutrition. Oil Palm is also useful in the production of non-food items such as: cosmetics, candles, soaps, electronics, pharmaceuticals, lubricants, surfactants, agrochemicals, leather and biodiesel. The versatility of the Oil Palm makes it a potential goldmine which Nigeria can tap into to counter the effects of crash in the price of crude oil.

\section{Restructure of the educational system}

The quality of product in the labour market relies heavily on the educational system and it is suggested that university education should address skills required in industry to ensure relevance (Akomolafe\&Adegun, 2009; Osagie, 2014). In addition, heavy investment in education is required so that it can attract foreign students and faculty. An attractive and world-class educational system would facilitate robust exchange programmes, which would not only enhance the quality of education in Nigeria but also attract income from international students. To solve the problem of unemployment, Nigerian educational and human capital development should be tied to the needs of the national economy.

\section{Vocational and technical education as a tool for employment generation}

Vocational education is important as its usefulness stretches from the individual beneficiary to the society at large. Vocational and technical education serves as an excellent instrument for making positive change in the individual's life and that of the society (Wodi, 2012). Vocational and technical education will help to improve the labour market in so many ways because it enables individuals acquire skills that are needed to make them become employable or be selfemployed and employers of labour. It will equally provide youths with needed skills that will take them out of the army of the unemployed in the labour market. This will therefore improve the labour market situation as unemployment rate will reduce.

\section{Improving infrastructural development in the rural areas}

Agriculture will also reduce the rural-urban migration. The revenue from oil in the 1970s gave the government the resources to invest in socio-economic infrastructures in the urban areas. The new investments made many able-bodied men to migrate to the urban areas thereby abandoning their farms with the hope of partaking in the oil driven economy. This created social problems such as pollution, congestions, unemployment and crimes (Oladipo \&Fabayo, 2012). Overhauling and improving the infrastructures in the rural areas will send people back to their traditional jobs such as agriculture and crafts and thereby provide employment opportunity for a large number of Nigerian population especially in the rural areas (Fajana, 2000). 


\section{Strengthening the security network in the country}

The Nigerian government revenue is tied to proceeds from oil such that oil price shocks immediately impact on virtually all economic prices in significant magnitude (Balouga, 2009). Apart from the challenges of global oil crisis, there is also reduction in the production capacity of the country as oil production facilities are severely disrupted in the wake of heightened thefts, bunkering and strategic vandalisation of oil producing facilities. The present unemployment rate in the Niger Delta Region of Nigeria is on the high side as about 1.8 million fresh graduates enter the labour market yearly (Agambi, 2015) cited in Omokhoa, 2015). The exit of investors and their organisations from the oil producing areas because of poor security situation means that a large number of workers will be sent back to the labour market thereby leading to further deterioration of the unemployment situation. Therefore, to improve the labour market situation, efforts should be made by the government to improve the security situation in the oil producing states of Nigeria.

To create a permanent solution to the challenges of restiveness in the Niger Delta, Omokhoa (2015) argues that programmes such as vocational training, job for the unskilled, economic empowerment and employment grants should be provided to address the problem of militancy in the region. Niger Delta people remain poor, unemployed and the region remains underdeveloped. Consequently, government should holistically develop the region; create employment for the restive youths as these are some of the causes of conflict in the Niger Delta. Improved security situation in Nigeria especially in the Niger Delta Region will help government maintain its production capacity in the mist of global oil price crisis

\section{Revitalise the ailing industries}

There is the need to invest and build new industries and most especially revitalising the existing industries that are operating below production capacities and those that are moribund. It is important to note that a major consequence of the drop in crude oil price in the global market is that Nigeria's foreign reserve will also drop. The need therefore arises for the government to look into revitalising such industries as textiles, manufacturing, steel, agro allied and mining among others. Nigeria is blessed with deposits of solid minerals such as iron ore, coal, lead, zinc, limestone, and tin and so on in commercial quantities. Nigerian Extractive Industries and Transparency Initiative (NEITI) (2012) reports that solid mineral sector is still a minor productive sector with low contributions to the main macro-economic areas of the economy and that it accounted for $0.02 \%$ of total export earnings and $0.14 \%$ of new employments in Nigeria by the end of 2012 .

In the same vein, Omoh (2015) states that NEITI reports shows that about 40 different kinds of solid minerals and precious metals remain unexploited in Nigeria while the Permanent Secretary of the Ministry of Mines and Steel argues that Nigeria is losing $\$ 8$ trillion (over $\$ 50$ billion) annually from gold exploitation alone. Improving these industries will help government harness their revenue and employment potentials. The essence of diversification of the economy should be job creation to absorb the large number of Nigerians who are unemployed or underemployed and those that could use a change of job to improve their economic status. 


\section{Conclusion and Recommendations}

This paper considered global oil prices and the opportunities open to improve the Nigerian labour market. The main findings revealed that the fall in crude oil price has negative consequences on the labour market in the short run but creates an opportunity for the government to improve the labour market situation by embarking on programmes in other sectors of the economy that could bring about improvement in the rate of employment. Also, the study reveals the dangers of mono-product economy and the consequences of fall in price of crude oil in the global market on Nigeria.

Based on the findings, the study recommends that focus of government should be on increasing the production capacities of other sectors of the economy, thereby decreasing unemployment in Nigeria. There is evidence that the global oil crisis has negative consequences on Nigeria labour market as crude oil is the major revenue driver for the nation. In view of the dangers associated with mono-product economy, it is also recommended that the Nigerian economy should be diversified to expand the revenue generating net and make Nigerian economy a multi-product economy.

This study has contributed to knowledge by establishing that low global oil prices create opportunities for nations to improve their labour market conditions. It has also established the need for Nigerian government to take advantage of the fall in oil prices to develop other sectors of the economy.

\section{REFERENCES}

Agbaeze, E. K., Udeh, S. N., \&Onwuka, I. O. (2015). Resolving Nigeria's dependency on oil: The derivation model. Journal of African Studies and Development, 7(1), 1-14.

Ahmad, F. (2013). The effect of oil prices on employment: Evidence from Pakistan. Business and Economics Research; 4(1) 43-57

Aigheyisi, O. S. (2013). The relative impacts of federal capital and recurrent expenditures on Nigeria's economy (1980-2011). American Journal of Economics, 3(5), 210-221.

Akomolafe, C. O. \&Adegun, O. A. (2009). Strategies of managing higher education for youth labour market in Nigeria. International NGO Journal, 4(10), 456-460.

Alley, I., Asekomeh, A., Mobolaji, H., Adeniran, Y. A. (2014). Oil price shocks and Nigerian economic growth. European Scientific Journal, 10(19), 375-391.

Baghebo, M. \&Atima, T. O. (2013). The impact of petroleum on economic growth in Nigeria. Global Business and Economics Research Journal, 2(5), 102-115.

Bahadorkhah, F. \&Aminifard, A. (2014). Investigating the relationship between the oil prices, interest rate and unemployment rate in Iranian economy. Indian Journal of Fundamental and Applied Life Sciences; 4(S1), 996-1004. Retrieved from wwwcibtech.org/sp.ed/jls/2014/01/jls.htm

Balouga, J. (2009). The global financial crisis and the oil and gas sector of Nigerian economy. International Association for Energy Economics, 31-34

Chude, N. P. \&Chude, D. I. (2013). Impact of government expenditure on economic growth in Nigeria. International Journal of Business and Management Review, 1(4), 64-71.

Denscombe, M. (2010). The good research guide: For small-scale social research projects $\left(4^{\text {th }}\right.$ ed.). Berkshire, England: McGraw-Hill 
Ember, C. R., \& Levinson, D. (1991). The substantive contributions of worldwide cross-cultural studies using secondary data. Behavior Science Research, 25(1-4), 79-140. http://dx.doi.org/10.1177/106939719102500105

Ekweozor, C. M. \&Unomah, G.I. (1990).First discovery of oil shale in the Benue Trough, Nigeria. Fuel, 69(4), 502-508. http://dx.doi.org/10.1016/0016-2361(90)90322-H

Fajana, S. (2000). Functioning of Nigerian labour market. Labofin and Company, Lagos

Gravetter, F. J. \&Forzano, L. B. (2009). Research methods for the behavioural sciences $\left(3^{\mathrm{rd}} \mathrm{ed}.\right)$, Belmont, CA: Wadsworth Centage Learning

Gylfason, T. (2001). Natural resources, education and economic development. European Economic Review, 45, 847-859.

Ibrahim, M. J. (2007). Growth prospects of oil and gas abundant economies: The Nigerianexperience (1970-2000). Retrieved from http://www.emeraldinsight.com/journals.htm?articleid=1724410\&show=pdf

Keshinro, O. A. (2014). Research process and statistical data analysis: A practical guideusing SPSS, Shomolu, Lagos: Tolantek Consulting ltd.

NEITI (2012). Solid mineral industry audit. Retrieved from www.neiti.org.ng

Nlerum, F. E. (2010). Reflections on participation regimes in Nigeria's oil sector. NigerianCurrent Law Review 2007-2010, 145-162.

Nwilo, P. C. \&Badejo, O. T. (2012).Impacts and management of oil spill pollution along the Nigerian coastal areas. Retrieved from http://cndsndu.org/index.php?option=com_content $\&$ view=article $\&$ id $=57:$ impacts-and-managementof-oil-spill-in-nigerian-coastal-environment\&catid=34:journals\&Itemid=41

Odularu, G. O. (2007). Crude oil and the Nigerian economic performance. Retrieved from http://www.ogbus.ru/eng/authors/odularo/odularo_1.pdf

Odularu, G. O. (2008). Crude oil and the Nigerian economic performance. Oil and Gas Business, 1-29. Retrieved from http://ogbus.ru/eng/authors/Odularo/Odularo_1.pdf

Ogwumike, F.O., Alaba, O. A., Alaba, O. B., Alayande, B. A., \&Okojie, C. E. E. (2006). Labour force participation, earnings and inequality in Nigeria. Retrieved from http://sarpn.org/documents/d0002270/Labour-force_Nigeria_Oct2006.pdf

Oladipo, S. O. \&Fabayo, J. O. (2012). Global recession, oil sector and economic growth in Nigeria. Asian Transactions on Basic and Applied Sciences (ATBAS ISSN: 2221-4267) 1(6), 29-41

Oluwatobi, S. O \&Ogunrinola, I. O. (2011). Government expenditure on human capital development: Implications for economic growth in Nigeria. Journal of Sustainable Development, 4 (3), 72-80.

Omoh, G. (2015). Neglect of solid Mineral: Why Nigeria remains poor. VanguardNewspaper Online, June 27, 2015. Retrieved from www.vanguardngr.com/2015/06

Omokhoa, I. E. (2015). Amnesty programme in Nigeria: Understanding justice and equity in the Niger delta region. International Journal of Public Administration and Management Research (IJPAMR), 3(2), 39-51

Omorogiuwa, O., Zivkovic, J.,Ademoh, F. (2014). The role of agriculture in the economic development of Nigeria. European Scientific Journal, 10(4), 134-147.

OPEC (2016). Nigeria facts and figures. Retrieved from http://www.opec.org/opec_web/en/about_us/167.htm

Osagie, R. O. (2014). Perspectives on higher education and the labour market outcomes in Nigeria. Journal of Educational and Social Research, 4(3), 125-130. 
Osigwe, A. C. (2015). Exchange rate fluctuations, oil prices and economic performance: Empirical evidence from Nigeria. International Journal of Energy Economics and Policy, $5(2), 502-506$.

PWC (2015). What next for Nigeria's economy? Navigating the rocky road ahead. PWC's economic scenarios for 2015 and 2016

Rosser, A. (2006). The political economy of the resource curse: A literature survey. IDS Working Paper 268.

Sanusi, L. S. (2010). Growth prospects for the Nigerian economy. Convocation Lecturedelivered at the Igbinedion University Eighth Convocation Ceremony, Okada, Edo State. Retrieved from http://www.cenbank.org/OUT/SPEECHES/2010/GOV_CONVOCATION_LECTUREIGBINEDION-UNIVERSITY-OKADA_2010.PDF

Saunders, M. N. K., Thornhill, A., \& Lewis, P. (2009). Research methods for business Students $\left(5^{\text {th }}\right.$ ed.). Harlow, England: FT-Pearson

Senzangakhona, P. \&Choga, I. (2015). Crude oil prices and unemployment in South Africa: 1990-2010. Mediterranean Journal of Social Sciences;6(2), 407-414

Tamuno, S. \& Felix, J. M. (2006).Crude oil resource: A blessing or curse to Nigeria - The case of the Niger Delta. Journal of Research in National Development, 4(2),53-58.

Tiku N. E. \&Bullem, F. A. (2015). Oil palm marketing, Nigeria-lessons to learn from Malaysia experience, opportunities and foreign direct investment in Cross River State. Journal of Development and Agricultural Economics, 7(7), 243-252.

Umoru, D. \&Yaqub, J. O. (2013). Labour productivity and health capital in Nigeria: The empirical evidence. International Journal of Humanities and Social Science, 3(4), 199221.

Wodi, S. W. (2012). Global economic crisis: A challenge to the entrepreneurial development of technical vocational education and training in oil and gas sector of the Nigerian economy. International Journal of Academic Research in Business and Social Sciences; 2(4). 